\title{
Temporal and comparative analysis between abdomen dissection methods for aorto-caval exposure
}

\author{
SATO, A. C. T. ${ }^{1}$ and BATIGÁlIA, F. ${ }^{2 *}$ \\ ${ }^{1}$ Faculdade de Medicina de São José do Rio Preto - FAMERP, Avenida Brigadeiro Faria Lima, 5416, \\ CEP 15091-000, São José do Rio Preto, SP, Brazil \\ ${ }^{2}$ Anatomy Department, Faculdade de Medicina de São José do Rio Preto - FAMERP, Avenida Brigadeiro Faria Lima, \\ 5416, CEP 15091-000, São José do Rio Preto, SP, Brazil \\ *E-mail: batigalia@famerp.br
}

\begin{abstract}
Introduction: The systemic exposure of the Human Body or dissection is considered of utmost importance by the study of abdominal vasculature, due to its applicability in Clinical Medicine, Surgery, Radiology and Pathology. The specialized literature does not mention comparative studies of time spent for execution of different dissection methods in order to prioritize the quickest method, and thereby, optimize academic or professional training in Anatomy or Emergency Surgery. The present research aimed at comparing the time required to perform dissection methods that prioritize the exposure of large abdominal vessels. Materials and Methods: Embalmed bodies of six adults were considered for execution (by the same professional) of Cattell-Braasch and Mattox maneuvers by manual blunt dissection or surgical instruments. Discussion: We evaluated the time spent for satisfactory completion of both maneuvers as well as for proper exposure of the large abdominal vessels, with statistical analysis using the Mann-Whitnney test with a $5 \%$ significance level. Conclusion: The Cattell-Braasch maneuver, blunt dissection or surgical instruments are similarly quick for folding of the cecum and adequate exposure of the inferior vena cava. For Mattox maneuver, blunt dissection is quicker compared to that performed by surgical instruments for the folding of the sigmoid colon and large aortic exposure.
\end{abstract}

Keywords: dissection, aorta, inferior vena cava, cattell-braasch, Mattox.

\section{Introduction}

The word anatomy, of Greek origin, means dissection (GALVÃO, 1994), and this, in turn, means "cut from" in Latin (FREITAS, 2004), which conceptually is the tissue systemic exposure to the studies (DORLAND, 1994; LAROUSSE, 1974) according to natural lines of cleavage (OSOL, 1982), both cadaveric preparations and during surgical procedures (ALVES, 1992).

Although the dissection of human corpses during the history of Anatomy has been the subject of scientific and ethical controversies (CASTRO and LANDEIRA-FERNANDEZ, 2011), and thus subject to socio-cultural and political changes that led to a ban on the method for 15 centuries (ŠTRKALJ and CHORN, 2008; MALOMO, IDOWU and OSUAGWU, 2006; JACKSON, 1992), its importance is uncontestable, especially the study of the vasculature, which is the topographical layout of blood vessels (TABER, 2000; OSOL, 1982; SIMÕES, GIRÃO, SASSO et al., 2014; PACIORNIK, 1978).

Currently, the dissection continues to prove its importance for anatomical study and in several specialties of medicine, such as Clinical Medicine, Surgery, Radiology and Pathology (POCHAT, MENDES, FIGUERÊDO et al., 2011; GUNDERMAN and WILSON, 2005; PONTINHA and SOEIRO, 2014). The increasing improvement of its dissection methods is mainly due to imagenological techniques such as ultrasonography, CT, MRI, endoscopy and PET scan (FITZGERALD, PORTS and YOCK, 1992).
However, the literature does not mention comparative studies of time spent for execution of different dissection methods in order to prioritize the quickest method and thus optimize the training in Anatomy or Emergency Surgery. This study aimed at comparing the time required to perform dissection methods that prioritize the exposure of large abdominal vessels.

\section{Materials and Methods}

Embalmed bodies of six male adults that legally belong to the Department of Anatomy, São José do Rio Preto Medical School (SP) were used in this research, without any abdominal preoperative procedures or causa mortis by abdominal pathologies.

We performed median longitudinal laparotomy by planes, in each body, to the level of the peritoneal cavity with incision of the anterior parietal peritoneum and the proximal folding of the greater omentum. Then, we proceeded to the exposure of large abdominal vessels (abdominal part of the descending aorta and inferior vena cava) by the Cattell-Braasch (BARANSKI, 2009) and Mattox maneuvers (NAVALÓN, HERNÁNDEZ and ORTEGA, 2009), performed by the same professional using manual blunt dissection or surgical instruments (Metzembaum ${ }^{\circledR}$ curved scissors and Kelly ${ }^{\circledR}$, Mixter $^{\circledR}$ and Duval ${ }^{\circledR}$ anatomical tweezers).

We also comparatively evaluated the time spent (in seconds) for the satisfactory performance of both maneuvers as well as for proper exposure of the large abdominal vessels. The considered 
variable included the time period required for the implementation of complete detachment of visceral subserosal screen in the right paracolic gutter and upper folding of the cecum to the left hypochondrium and adequate inferior vena cava exposure during Cattell-Braasch maneuver.

For Mattox maneuver, we thought it was necessary to evaluate the time required to have full detachment of the visceral subserosal screen in the left paracolic gutter, upper folding of sigmoid and descending colon close to the right hypochondrium and adequate exposure of the aorta. Statistical analysis was performed using the Mann-Whitnney test (MARÔCO, 2011), with the adoption of a $5 \%$ significance level.

\section{Results}

Table 1 shows the comparative statistical analysis between the period of time required for the implementation of complete detachment of the visceral subserosal screen in the right paracolic gutter during Cattell-Braasch maneuver, with manual blunt dissection or surgical instruments. There was no statistically significant difference between blunt dissection or surgical instruments for the implementation of complete detachment of visceral subserosal screen during Cattell-Braasch maneuver.

Table 2 show the comparative statistical analysis of time required for execution of the upper folding of the cecum to the left hypochondrium and adequate inferior vena cava during Cattell-Braasch maneuver with manual blunt dissection (Figure 1) or surgical instruments. There was no statistically significant difference between blunt dissection and surgical instruments for the upper folding of the cecum to the left hypochondrium and adequate inferior vena cava exposure during Cattell-Braasch maneuver.

Table 3 explains the comparative statistical analysis between the period of time needed to perform complete displacement of visceral subserosal screen in the left paracolic gutter during Mattox maneuver, with blunt dissection or surgical instruments (Figure 2). There was a statistically significant difference between blunt dissection and surgical instruments for the implementation of the upper folding of the cecum to the left hypochondrium and exposure of the aorta during Mattox maneuver, with shorter execution time by blunt dissection.

Table 4 shows the comparative statistical analysis between the period of time required for execution of the upper folding of the sigmoid colon close to the right hypochondrium and adequate exposure of the aorta during Mattox maneuver, with blunt dissection or surgical instruments. There was a statistically significant difference between blunt dissection or surgical instruments for the implementation of the upper folding of sigmoid colon close to the right hypochondrium

Table 1. Comparative statistical analysis between period of time required for the implementation of complete detachment of visceral subserosal screen in the right paracolic gutter during Cattell-Braasch maneuver, with blunt dissection or surgical instrument $(\mathrm{s}=\mathrm{seconds})$.

\begin{tabular}{ccc}
\hline Measures of Central Tendency & Blunt Dissection & Dissection with Surgical Instrument \\
\hline Arithmetic Mean & $286.75 \mathrm{~s}$ & $463.25 \mathrm{~s}$ \\
Standard Deviation & $43.84 \mathrm{~s}$ & $113.94 \mathrm{~s}$ \\
Median & $299.50 \mathrm{~s}$ & $479.00 \mathrm{~s}$ \\
\hline
\end{tabular}

Mann-Whitney test: P-value $=0.0571$.

Table 2. Comparative statistical analysis between time required for execution of the upper folding of the cecum to the left hypochondrium and adequate inferior vena cava exposure during Cattell-Braasch maneuver, with blunt dissection or surgical instrument ( $\mathrm{s}=\mathrm{seconds}$ ).

\begin{tabular}{ccc}
\hline Measures of Central Tendency & Blunt Dissection & Dissection with Surgical Instrument \\
\hline Arithmetic Mean & $533.00 \mathrm{~s}$ & $673.50 \mathrm{~s}$ \\
Standard Devition & $60.65 \mathrm{~s}$ & $11.70 \mathrm{~s}$ \\
Median & $552.00 \mathrm{~s}$ & $688.50 \mathrm{~s}$ \\
\hline
\end{tabular}

Mann-Whitney test: $P$-value $=0.1143$.

Table 3. Comparative statistical analysis between the period of time needed to perform complete displacement of visceral subserosal screen in the left paracolic gutter during Mattox maneuver, with blunt dissection or surgical instrument $(\mathrm{s}=\operatorname{seconds})$.

\begin{tabular}{ccc}
\hline Measures of Central Tendency & Manual Blunt Dissection & Dissection with Surgical Instrument \\
\hline Arithmeric Mean & $338.00 \mathrm{~s}$ & $513.75 \mathrm{~s}$ \\
Standard Deviation & $73.54 \mathrm{~s}$ & $44.87 \mathrm{~s}$ \\
Median & $344.50 \mathrm{~s}$ & $463.00 \mathrm{~s}$ \\
\hline
\end{tabular}

Mann-Whitney test: P-value $=0.0286$.

Table 4. Comparative statistical analysis between the period of time required for execution of the upper folding of the sigmoid colon close to the right hypochondrium and adequate exposure of the aorta during Mattox maneuver, with blunt dissection or surgical instrument ( $\mathrm{s}=$ seconds $)$.

\begin{tabular}{ccc}
\hline Measures of Central Tendency & Blunt Dissection & Dissection with Surgical Instrument \\
\hline Arithmetic Mean & $438.25 \mathrm{~s}$ & $770.50 \mathrm{~s}$ \\
Standard Deviation & $45.65 \mathrm{~s}$ & $69.01 \mathrm{~s}$ \\
Median & $428.50 \mathrm{~s}$ & $775.00 \mathrm{~s}$ \\
\hline
\end{tabular}

Mann-Whitney test: P-palue $=0.0209$. 


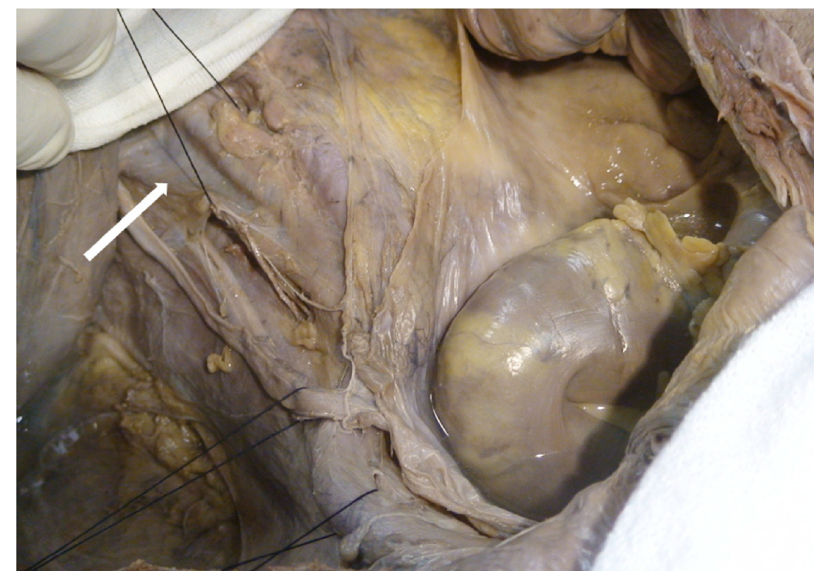

Figure 1. Performance of Cattell-Braasch maneuver by manual blunt dissection with inferior vena cava exposure (arrow).

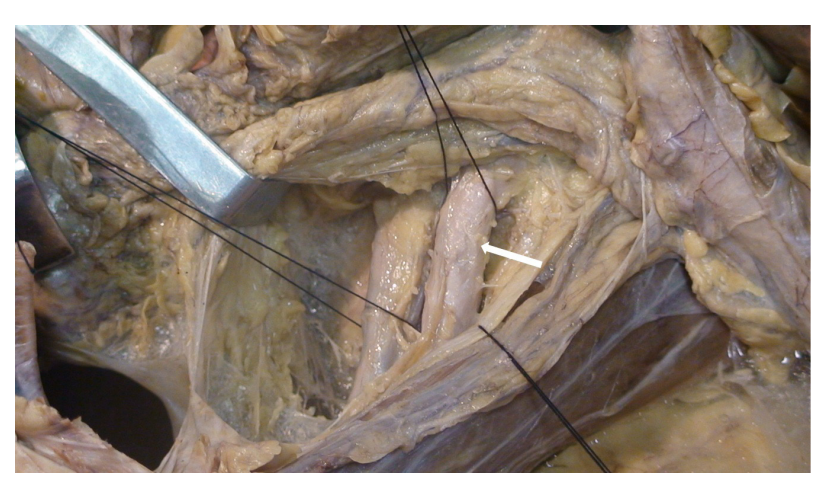

Figure 2. Performance of Mattox maneuver by dissection with surgical instruments, exposing the abdominal part of the descending aorta (arrow).

and adequate exposure of the aorta during Mattox maneuver, with shorter execution time by blunt dissection.

\section{Discussion}

The present research aimed to compare the time spent to perform the Cattell-Braasch and Mattox maneuvers by the blunt dissection method or with surgical instruments in order to optimize the exposure of large abdominal vessels.

In abdominal surgeries, the duration of time of the procedure is extremely important, especially for risk operations involving abdominal vessels, since vascular surgeries have the highest mortality rates compared to other medical specialties (MENDONÇA, MOREIRA, TIMI et al., 2005). In addition, surgical time is one of three main variables responsible for the postoperative success (CICARELLI, GOTARDO, JUNIOR et al., 1998).

The Cattell-Braasch (BARANSKI, 2009) and Mattox (NAVALÓN, HERNÁNDEZ and ORTEGA, 2009) maneuvers have been successfully adopted in abdominal surgery and, in certain situations, is the only way for exposure and safe approach to vital structures. As an example, Cattell-Braasch maneuver allows proper manipulation of the duodenum (HENRIQUES, 2009), while Mattox maneuver exposes the abdominal portion of the descending aorta (SPENCER NETTO, SILVA and ALBUQUERQUE, 2004).
In this study, during the incision situations of visceral subserosal screen in paracolic gutters and folding of the large intestine segments, manual dissection was quicker (Table 3 and 4), but only for procedures performed by Mattox maneuver. In this context, it is worth mentioning the difference in arithmetic means of the time required to perform the Mattox maneuver during the folding of the sigmoid and descending colon and adequate exposure of the aorta, in which there was the greatest difference in time between blunt dissection and surgical instruments (Table 4).

The anesthetic success depends essentially on the patient monitoring, time division in multiple procedures during surgery and rapid decision-making capacity of the anesthesiologist during non-routine events (WEINGER and SLAGLE, 2002). Since the duration of the surgery is related to the extent of volume loss, the factor time is important to ensure therapeutic success (MEYER, COUTINHO, GOUVEIA et al., 2012). Such evidence proves the relevance of comparative research on anatomico-surgical elements can minimize the duration of high-risk surgeries. This study provides an indication that blunt dissection during Mattox maneuver is an efficient alternative to the folding of the sigmoid colon and large aortic exposure.

\section{Conclusions}

In order to perform the Cattell-Braasch maneuver, blunt dissection or dissections with surgical instruments are similarly quick to the folding of the cecum and adequate exposure of the inferior vena cava. When performing the Mattox maneuver, blunt dissection is quicker compared to that performed by surgical instruments for the folding of the sigmoid colon and large aortic exposure.

\section{References}

ALVES, E. Dicionário médico inglês-português. Rio de Janeiro: Atheneu, 1992. 79 p.

BARANSKI, A. Surgical technique of the abdominal organ procurement. London: Springer-Verlag, 2009. p. 45-53 p.

CASTRO, FS. and LANDEIRA-FERNANDEZ, J. Alma, corpo e a antiga civilização grega: as primeiras observações do funcionamento cerebral e das atividades mentais. Psicologia: Reflexão e Critica, 2011, vol. 24 , n. 4 , p. 802-805. http://dx.doi.org/10.1590/S010279722011000400021.

CICARELLI, DD., GOTARDO, ADOM., JUNIOR, A., COSTA, JO., OLIVETTI, GT. and OLIVEIRA, FS. Incidência de óbitos anestésicos-cirúrgicos nas primeiras 24 horas: revisão de prontuários de 1995 no Hospital das Clínicas da FMUSP. Revista Brasileira de Anestesiologia, 1998, vol. 48, p. 289-294.

DORLAND, WAN. Dorland's illustrated medical dictionary. Filadélfia: W.B. Saunders, 1994. 496 p.

FITZGERALD, PJ., PORTS, TA. and YOCK, PG. Contribution of localized calcium deposits to dissection after angioplasty. An observational study using intravascular ultrasound. Circulation, 1992, vol. 86, n. 1, p. 64-70. PMid:1617791. http://dx.doi.org/10.1161/01.CIR.86.1.64.

FREITAS, V. Anatomia: conceitos e fundamentos. Porto Alegre: Artmed, 2004. 19 p.

GALVÃO, R. Vocabulário etimológico, ortográfico e prosódico das palavras portuguesas derivadas da lingua grega. Belo Horizonte: Garnier, 1994. p. 47-48. 
GUNDERMAN, RB. and WILSON, PK. Exploring the human interior: The roles of cadaver dissection and radiologic imaging in teaching anatomy. Academic Medicine, 2005, vol. 80, n. 8, p. 745749. PMid:16043529. http://dx.doi.org/10.1097/00001888200508000-00008.

HENRIQUES, PRF. Traumatism Duodenal. Bibliomed, 2009. chap. 18. Available from: <http://www.bibliomed.com.br/bibliomed/ bmbooks/urgencia/livrol/cap/capl8.htm>. Access in: 16 Mar. 2016.

JACKSON, BT. The new Aird's companion in surgical studies: An introduction to the history of Surgery. London: Churchill Livingstone, 1992. p. 1-26.

LAROUSSE, DA. Grande Enciclopédia. Rio de Janeiro: Delta S, 1974. 2224 p.

MALOMO, AO., IDOWU, OE. and OSUAGWU, FC. Lessons from history: human anatomy, from the origin to the renaissance. International Journal of Morphology, 2006, vol. 24, n. 1, p. 100-104. http://dx.doi.org/10.4067/S0717-95022006000100018.

MARÔCO, J. Análise estatística com o SPSS Statistics. ReportNumber Lda., 2011. p. 303-321.

MENDONÇA, CT., MOREIRA, RCR., TIMI, JRR., MIYAMOTTO, M., MARTINS, M., STANISCHESK, IC., DELVALLE, CE. and JARABIZA, R. Comparação entre os tratamentos aberto e endovascular dos aneurismas da aorta abdominal em pacientes de alto risco cirúrgico. Jornal Vascular Brasileiro, 2005, vol. 4, n. 3, p. 239. http://dx.doi. org/10.1590/S1677-54492005000300004.

MEYER, F., COUTINHO, DJ., GOUVEIA, DSS., LIZANA, JN. and DZIEDRICKI, LF. Laparoscopic nephrectomy with single-portal access Sitracc ${ }^{\circledast}$ in swines. Acta Cirurgica Brasileira, 2012, vol. 27, n. 3, p. 231-235. PMid:22460253. http://dx.doi.org/10.1590/ S0102-86502012000300005.

NAVALÓN, JMJ., HERNÁNDEZ, AC. and ORTEGA, I. Complex surgical techniques to control bleeding. Cirugia Espanola, 2009, vol. 85, supplement 1, p. 35-39. PMid:19589408.
OSOL, A. Dicionário médico Blakiston. São Paulo: Andrei, 1982. 1083 p.

PACIORNIK, R. Dicionário médico. Rio de Janeiro: Guanabara Koogan, 1978. 104 p.

POCHAT, VD., MENDES, RRDS., FIGUERÊDO, AAD., ALONSO, N., CUNHA, MS. and MENESES, JVL. Cadaver dissection activities in medical residency: experience of the Plastic Surgery Service of Hospital Universitário Professor Edgard Santos, Universidade Federal da Bahia. Revista Brasileira de Cirurgia Plástica, 2011, vol. 26, n. 4, p. 561-562.

PONTINHA, CM. and SOEIRO, C. A dissecação como ferramenta pedagógica no ensino da Anatomia em Portugal. Interface: Comunicação, Saúde, Educação, 2014, vol. 18, n. 48, p. 169-170. http://dx.doi. org/10.1590/1807-57622014.0558.

SIMÕES, RS., GIRÃO, JHRC., SASSO, GRS., SILVA, RF., ALONSO, LG. and MARQUES, SR. Etimologia de termos Morfológicos. São Paulo: Unifesp, 2014. Available from: <http://www2.unifesp.br/ dmorfo/Prof\%20Manoel\%20Histologia/Dicionario\%20etimologico. pdf>. Access in: 16 Mar. 2016.

SPENCER NETTO, FAC., SILVA, AP. and ALBUQUERQUE, MCS. Arma branca retida em aorta abdominal superior. Revista do Colégio Brasileiro de Cirurgiões, 2004, vol. 31, n. 5, p. 340-341. http:// dx.doi.org/10.1590/S0100-69912004000500013.

ŠTRKALJ, G. and CHORN, D. Herophilus of Chalcedon and the practice of dissection in Hellenistic Alexandria. South African Medical Journal, 2008, vol. 98, n. 2, p. 86-89. PMid:18350197.

TABER, J. Dicionário médico enciclopédico. São Paulo: Manole, 2000. 1816 p.

WEINGER, MB. and SLAGLE, J. Human factors research in anesthesia patient safety. Journal of the American Medical Informatics Association, 2002, vol. 9, supplement 6, p. S58-S63.

Received March 16, 2016 Accepted June 25, 2017 